\title{
Early Childhood Caries and sugar: relationships and suggestions for prevention
}

\author{
Cárie da primeira infância e açúcar: relações \\ e sugestões para prevenção
}

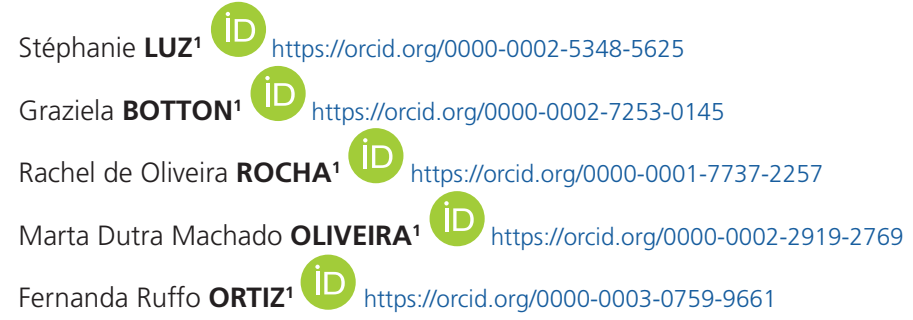

\section{ABSTRACT}

Objective: To show the relation between sugar intake in the infant diet and the presence of early childhood caries in a group of preschoolers. Methods: A retrospective analysis of medical records of patients aged 0 to 6 years attended at the Clinic of Babies from 2010 to 2016, at Universidade Federal de Santa Maria. The data analyzed were: patient identification, gender, age, sugar introduction (age and frequency), exclusive breastfeeding, use of a bottle containing sugar, brushing (with or without fluoride) and diagnosis of dental caries through the International Caries Detection and Assessment System. Descriptive analysis showed the characteristics of the sample and comparison analyzes were performed using Fisher and T-Student tests, to verify the relation between individual variables and sugary intake. Results: The average age of the children was 29 months. Of the 86 medical records analyzed, $80.0 \%$ of the children ingested sugary foods, and its were part of the eating routine. Only 36 medical records contained information about early childhood caries, in which $86.2 \%$ of prevalence was found. There was no statistical difference between sugary diet and other variables $(p>0.05)$. Conclusion: These results suggest an intense relationship between sugar and early childhood caries. The high frequency of sugar intake is a risk factor for the onset of caries in early childhood, and its insertion in infant feeding may be delayed. Food and hygiene orientation is fundamental in the treatment process as well as family awareness.

Indexing terms: Child, preschool. Dental caries. Sucrose.

\section{RESUMO}

Objetivo: Mostrar a relação entre a ingestão do açúcar na dieta infantil e a presença da Cárie da Primeira Infância em um grupo de crianças pré-escolares. Métodos: Foi realizada uma análise retrospectiva de prontuários de pacientes de 0 a 6 anos atendidos na Clínica de Bebês entre 2010 a 2016, da Universidade Federal de Santa Maria. Os dados analisados foram: identificação do paciente, sexo, idade, introdução do açúcar (idade e frequência), aleitamento materno exclusivo, uso de mamadeira contendo açúcar, escovação

$\nabla \nabla \nabla \nabla$

1 Universidade Federal de Santa Maria, Faculdade de Odontologia, Departamento de Estomatologia. Av. Roraima, 1000, Prédio 26F, Camobi, 97105-900, Santa Maria, RS, Brasil. Correspondence to: FR ORTIZ. E-mail: <fernandaruffoortiz@gmail.com>.

$\mathbf{v} \mathbf{v}$

How to cite this article

Luz S, Botton G, Rocha RO, Oliveira MDM, Ortiz FR. Early childhood caries and sugar: relationships and suggestions for prevention. RGO, Rev Gaúch Odontol. 2021;69:e20210054. http://dx.doi.org/10.1590/1981-863720210005520200027 
(com ou sem flúor) e diagnóstico de cárie dentária feito através do International Caries Detection and Assessment System. A análise descritiva mostrou as características da amostra e análises comparativas foram realizadas pelos testes de Fisher e T-Student, para verificar a relação entre variáveis individuais e a ingestão de açucares. Resultados: A média de idade das crianças foi de 29 meses. Dos 86 prontuários analisados, 80,0\% das crianças ingeriam alimentos açucarados, sendo parte da rotina alimentar. Apenas 36 prontuários continham informações sobre a Cárie da Primeira Infância, nestes foi encontrada uma prevalência de 86,2\% da amostra. Não houve diferença estatística entre dieta açucarada e demais variáveis ( $p>0,05)$. Conclusão: Esses resultados sugerem uma intensa relação entre açúcar e Cárie da Primeira Infância. A alta frequência de ingestão de açúcar é um fator de risco para o surgimento da Cárie da Primeira Infância, podendo ser retardada a sua inserção na alimentação infantil. A orientação alimentar e de higienização é fundamental no processo do tratamento assim como a conscientização familiar.

Termos de indexação: Pré-escolar. Cárie dentária. Sacarose.

\section{INTRODUCTION}

Dental caries is a process developed by dental biofilm, which promotes acid attacks on dental structures in the presence of fermentable sugars and carbohydrates, through the demineralization process [1]. This is a disease considered multifactorial by some authors, as it requires not only one, but also several agents for its development, as well as a susceptible tooth, microorganisms and diet [2]. Other authors also question this multifactoriality, since the bacteria are already present in the oral environment and the process is only given in the presence of sugar, which it is the main factor [3].

Early Childhood Caries (ECC) is studied for long time. It is terminology has been constantly modified, since it was associated with some of its factors and not with everyone's compilation [4]. Currently, the term ECC, originally from the English language, deserves a greater emphasis. It is a term that represents results of associations of different causes [5]. However, it is translation into Portuguese is still undergoing modifications and the most current and vast term is Early Childhood Caries.

The evidence that sugar to harm to health of the individual seems to be evident, being a risk factor for other chronic and systemic diseases, besides the dental caries [4]. The high frequency consumption is a risk agent for the development of ECC, being present in the eating habits of the family and not only of the child. In addition to sugar, demographic and socioeconomic factors at the family and community level are also associated with the prevalence of ECC [6]. The education level of caregivers, especially the mother, access to health and family income are some direct influences with the disease $[7,8]$, which eating habits and behaviors, and oral hygiene routine are influenced and depend on parents / responsible.

On the other hand, it is essential to have the knowledge of the causal factors to prevent and to initiate appropriate treatment, respecting the individuality of each patient. Sugar is a constant food in children's routine and it is role is fundamental in the appearance of ECC. Therefore, the aim of this study was to show the relationship between sugar intake in the children's diet and the presence of Early Childhood Caries in preschool children, attended at a school clinic.

\section{METHODS}

This is a retrospective cross-sectional study. The data were used from medical records of patients aged 0 to 6 years, attended at the "Baby Clinic" at the Federal University of Santa Maria, Brazil. The Clinic is a discipline offered to postgraduate students, at the master's level, who attend preschoolers from their preventive to therapeutic needs.

The records survey was carried out through a convenience sample of patients who had already completed their care at the Clinic, corresponding to the years 2010 to 2016. From these, a retrospective analysis was performed through: patient identification, gender, age, sugar introduction (age and frequency), exclusive breastfeeding for 6 months, use of a bottle containing sugar, brushing (with or without fluoride). This information was obtained through answers to parents / guardians of the anamnesis, at prior to the clinical examination. Medical records with more than two missing information were excluded from the analysis.

The diagnosis of dental caries was assessed using the International Caries Detection and Assessment System index (ICDAS), which performs the detection of dental caries through codes 0 to 6 , involving from white spot lesions (codes 1 and 2), to cavities enamel (code 3) and dentin (codes 5 and 6) [9]. The diagnosis of dental caries was considered when the medical record contained the 
presence of white spot lesions or cavities in enamel and dentin.

Statistical analysis was performed using the Stata software (Stata Corporation, College Station, TX, USA, version 14.0). Descriptive analysis showed the characteristics of the sample, by frequencies and percentages, as well as measures of central tendency and dispersion. Comparison analyzes were also performed using Fisher and T-Student tests, to verify the comparison between individual variables and the use of sugary intake by preschoolers.

\section{RESULTS}

A total of 109 records were analyzed. However, only 36 contained ECC information and 23 were excluded for not containing diet and dental caries information.

Table 1. Characteristics of the sample.

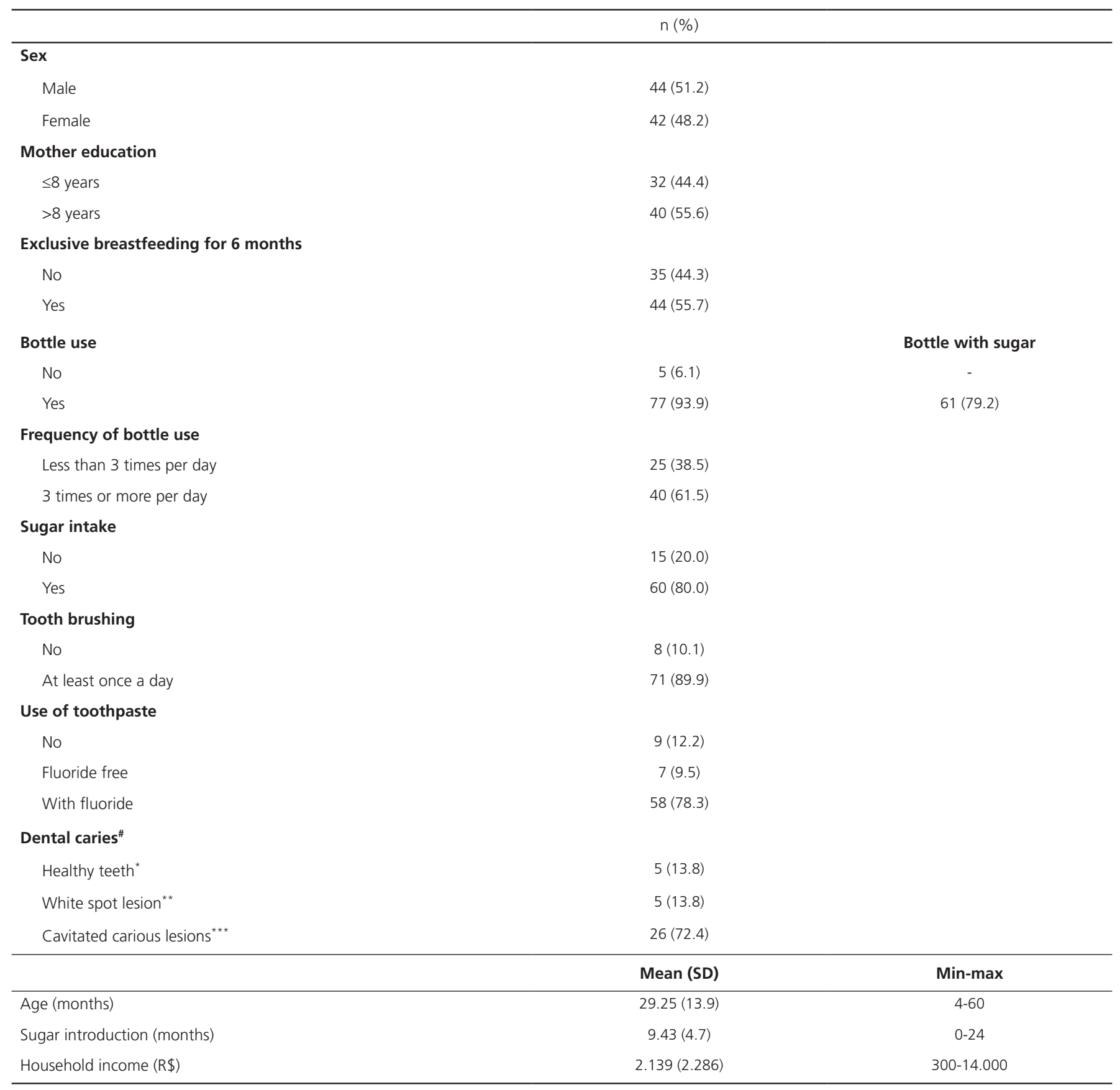

Note: SD: standard deviation; " ICDAS: scores 0; ${ }^{* *}$ ICDAS: scores 1 and 2; ${ }^{* * *}$ ICDAS: scores 5 and 6; ${ }^{*}$ number of individuals with dental caries. 
The sample was equivalent between boys and girls. Most mothers had not completed high school, and the household income mean was of $R \$ 1.500,00$. The mean age of children on the day of the dental care was of 29 months. The introduction of sugar occurred on average at 9 months of age, and most children sugary intake (80.0\%), such as candies, cakes and cookies. Tooth brushing was performed on all children by parents / guardians, mostly with the use of fluoride toothpaste (78.3\%). Not all the records and diagnoses of dental caries were contained; however, those that did, most children have already arrived at the dental clinic with cavitated carious lesions in dentin (72.4\%) (table 1).

Table 2 shows comparative analysis between individual variables and sugary intake. There was no statistical difference between sex, age, maternal education, household income, breastfeeding and bottle use variables compared to individuals who were using or not a sugary diet.

\section{DISCUSSION}

This study evaluated a sample of preschool attended at university. The results show that the introduction to sugar was on average at 9 months of age, and that almost all children used a bottle, added to some type of sugar.
Most of the analyzed dental caries had cavitated carious lesions. Furthermore, there was no difference between individual variables through the use or not of sugary diet, that is, regardless of gender, family socioeconomic factors and breastfeeding, children ingested sugar equally.

It seems to be remarkable that the vast majority of the consultations performed in this clinic were curative, where patients sought dental care when the disease had already presented complex treatment. The mean age of the day of the first consultation was 29 months, and the average age of introduction to sugar was 9 months, that is, after the introduction of sugar, the child took an average of almost two years to seek dental care. Therefore, the consumption of sugar seems to be constant in the diet of these children.

Dietary patterns from 6 to 24 months of age are strongly influenced by mothers and other primary caregivers [10]. Studies on babies sugar intake focused on patterns or eating habits [10-12]. In other words, mothers whose own diet was characterized by high consumption of carbohydrates and sugars were more likely to have their babies having a high consumption of them $[10,11]$. When the presence of cariogenic food practices were investigated, mothers infants with low education had higher risk of having such dietary practices cariogenic than mothers who had higher education [11]. The frequency

Table 2. Comparative analysis between children's individual variables and sugar introduction.

\begin{tabular}{|c|c|c|c|}
\hline & \multicolumn{2}{|c|}{ Sugar intake } & \multirow{2}{*}{ P-value } \\
\hline & No & Yes & \\
\hline Sex & & & $0.08^{*}$ \\
\hline Female & $4(11.1)$ & $32(88.9)$ & \\
\hline Mother education & & & $0.11^{*}$ \\
\hline$>8$ years & $9(27.3)$ & $24(72.7)$ & \\
\hline Exclusive breastfeeding for 6 months & & & $0.38^{*}$ \\
\hline No & $9(27.3)$ & $24(72.7)$ & \\
\hline Yes & $5(13.5)$ & $33(86.5)$ & \\
\hline Age (months) ${ }^{\#}$ & $28.2(18.7)$ & $29.7(12.8)$ & $0.70^{\star *}$ \\
\hline Household income ${ }^{\#}$ & $2.347(3,543)$ & $2.113(2,049)$ & $0.75^{* *}$ \\
\hline
\end{tabular}

Note: " Mean (Standard Deviation); ${ }^{*}$ Fisher test; ${ }^{* *}$ T Student test. 
of sugar ingestion in the early phase of children leads to a predilection for the taste of sugary foods, which may influence eating habits in the later stages of life, and may be related to diseases, such as obesity and type 2 diabetes [13].

The last epidemiological survey on oral health found that $53.5 \%$ of Brazilian children 5 years-old already had some experience of dental caries [14]. One of the possible aggravating factors for the development of ECC may be the child's early independence in brushing, since it does not have the fine motor skills developed enough. In view of this, brushing efficiency requires frequency, technique and adequate time, requirements that a child up to 6 years-old does not have, neither the maturity to assimilate nor the manual dexterity to perform a correct removal of the dental biofilm $[15,16]$.

Kuriakose et al. [17] observed the relationship between Early Childhood Caries and the higher demand for visits to the dentist, finding that the demand for dental services for children only occurred, in the vast majority, when there was some type pain or discomfort. This only proves that the population seeks the service when the problem is already installed and not as a form of prevention, thus showing the lack of knowledge of the importance of visiting the professional both in terms of prevention and when it comes to therapeutic intervention care [18].

On the other hand, the prevention of ECC begins well before the onset of the disease, before the rupture of teeth in the oral cavity and even the birth of the child. Health professionals who adequately transmit preventive educational information to parents and guardians prove to be effective in reducing the prevalence of ECC [13]. The education levels of the main caregivers, especially the mother, have a significant impact on the child's life, and can be a protective factor against caries $[19,20]$. The knowledge of caregivers is fundamental for the prevention of dental caries in view of the importance of oral hygiene habits, with the pioneering role of brushing, in addition to eating habits and visits to the dentist [21]. The lack of information, common to people with a low level of education, may negatively enhance the child's oral health condition [14]. Therefore, for the prevention of ECC is essential a multidisciplinary approach in the health area, aiming to reach not only the child, but also the family as a whole.

The impact of early prevention cannot be underestimated, as it was found that children with dental caries in primary teeth are 3 times more likely to have permanent tooth decay as adults, negatively affecting the individual's quality of life, with cumulative effects over the years [22]. The contact of fluorides with the teeth is also essential for their protection, not being able to treat them as villains, but as essential for the hygiene routine, since the eruption of the first tooth. It use is a fundamental, effective and safe instrument in the prevention and control of caries when used correctly [14].

The American Academy of Pediatric Dentistry (AAPD) suggests the use of fluoride toothpaste (at a concentration of 1,000 ppm F) twice a day, since the eruption of the first deciduous tooth, using a brush of adequate size and compatible with the size of the oral cavity of the child, being preferably soft. Children under 3 years of age, the recommended amount of fluoride toothpaste is that of a "grain of rice", and in children aged 3 to 6 years, the amount should be similar to the size of a "pea grain" [23].

Perform retrospective studies with medical records has some limitations. The difficulties found were mainly the filling errors, becoming a limiting factor in this study. Thus, there were files with misinterpretations regarding the questions asked, as well as files with incomplete and poorly filled information.

Regarding the eating habits developed by children with a predisposition for sugar, it also stands out the advertising around the sugar industries is currently dull. Colorful and flashy packaging, commercials with animated characters, music and associations to health and pleasure are evident to stimulate purchase and consumption, especially for consumers who are highly influential, such as children. To have awareness that the presence of sugar in industrialized products is high, it is already the beginning of the process, where selecting the foods that the child eats will be essential for health as a whole.

Aiming at this, public policies are necessary for the intervention of food advertisements targeted children, highlighting the harmful effects caused to health [3]. Hinder access to these types of foods, by raising taxes is a step to be taken, as well as removing associations with children's characters in packaging and reducing availability in school canteens, can be strategies to solve the decrease in sugar food consumption [24].

\section{CONCLUSION}

Dental caries is a highly prevalent disease that affects all generations. The causes of this disease are still 
discussed by several authors, but it is evident that sugar has a fundamental role in its development. Our findings show that children start sugar intake before their first year of life, and those who seek dental care already have advanced dental caries.

In early childhood, the child is developing their predilections and getting to know new flavors and tastes, where it only chooses what it knows, leaving it to the parents or guardians to select what they will eat. Therefore, delaying the insertion of sugar in infant feeding or reducing its frequency is essential for your health, as its high frequency is a risk factor for ECC.

Intense guidance on proper diet and hygiene is fundamental in the prevention of ECC, which awareness seems to be the initial and crucial measure for the prevention and treatment of dental caries.

\section{Collaborators}

S LUZ conceived the article, compiled the data and wrote the draft of the manuscript. G Botton was responsible for the design and critical review of the manuscript. RO ROCHA and MDM OLIVEIRA review critically the manuscript for important intellectual content. FR ORTIZ was responsible for the design, data analysis, wrote and critical review of the manuscript. All authors read and approved the final manuscript.

\section{REFERENCES}

1. Fejerskov O, Larsen MJ. Demineralization and remineralisation: the key to understanding clinical manifestations of dental caries. In: Fejerskov O, Nyvad B, Kidd E, editors. Dental caries: the disease and its clinical management. 3rd ed. Oxford (UK): Wiley Blackwell; 2015. p.160-169.

2. Lima JEO. Dental caries: a new concept. R Dental Press Ortodon Ortop Facial. 2007;12(6):119-130. https://dx.doi. org/10.1590/S1415-54192007000600012

3. Sheiham A, James WPT. Diet and dental caries: the pivotal role of free sugars reemphasized. J Dental Res. 2015;94(10):1341-1347. https://dx.doi.org/10.1177/0022034515590377

4. Tinanoff N, Baez RJ, Diaz Guillory C, Donly KJ, Feldens CA, McGrath C, et al. Early childhood caries epidemiology, aetiology, risk assessment, societal burden, management, education, and policy: global perspective. Int J Paediatr Dent. 2019;29:238-248. https://dx.doi.org/10.1111/ipd.12484

5. Innes NPT, Frencken JE, Bjørndal L, Maltz M, Manton DJ, Ricketts $D$, et al. Managing carious lesions: consensus recommendations on terminology. Adv Dent Res. 2016;28(2):49-57. https:// dx.doi.org/10.1177/0022034516639276
6. Kramer PF, Chaffee BW, Bertelli AE, Ferreira SH, Beria JU, Feldens CA. Gains in children's dental health differ by socioeconomic position: evidence of widening inequalities in Southern Brazil. Int J Paediatr Dent. 2015;25:383-392. https://dx.doi.org/10.1111/ipd.12140

7. Correa-Faria P, Martins-Junior PA, Andrade RGV, Marques LS, Ramos-Jorge ML. Factors associated with the development of early childhood caries among Brazilian preschoolers. Braz Oral Res. 2013;27(4):356-362. https://dx.doi.org/10.1590/S180683242013005000021

8. Darmawikarta D, Chen Y, Carslev S, Birken CS, Parkin PC, Schroth RJ, Maguire JL. Factors Associated With Dental Care Utilization in Early Childhood. Pediatrics. 2014;133(6):1594-600. http://dx.doi.org/10.1542/peds.2013-3725

9. Gugnani N, Pandit IK, Srivastava N, Gupta M, Sharma M. International caries detection and assessment system (ICDAS): A new concept. Int J Clin Pediatr Dent. 2011;4(2):93.

10. Robinson S, Marriott L, Poole J, Crozier S, Borland S, Lawrence $W$, et al. Dietary patterns in infancy: the importance of maternal and Family influences on feeding practice. $\mathrm{Br} \mathrm{J}$ Nutr. 2007;98:1029-1037. https://dx.doi.org/10.1017/ S0007114507750936

11. Feldens CA, Kramer PF, Sequeira MC, Rodrigues PH, Vitolo MR. Maternal education is an independent determinant of cariogenic feeding practices in the first year of life. Eur Arch Paediatr Dent. 2012;13:70-75. https://dx.doi.org/10.1007/ bf03262847

12. Contreras M, Blandón EZ, Persson LÅ, Hjern A, Ekström EC. Socio-economic resources, young child feeding practices, consumption of highly processed snacks and sugar-sweetened beverages: a population-based survey in rural northwestern Nicaragua. BMC Public Health. 2015;15:25. httpss://dx.doi. org/10.1186/s12889-015-1374-1375

13. Joury E, Khairallah M, Sabbah W, Elias K, Bedi R. Inequalities in the frequency of free sugars intake among Syrian 1-year-old infants: a cross-sectional study. BMC Oral Health. 2016;16:94. https://dx.doi.org/10.1186/s12903-016-0287-8

14. Silva MG, Catão MH, Andrade FJ, Alencar C. Early childhood caries: associated risk factors. Arch Health Invest. 2017;6(12):574-579. https://dx.doi.org/10.21270/ archi.v6i12.2264

15. Prakash $P$, Subramaniam $P$, Durgesh $B H$, Konde S. Prevalence of early childhood caries and associated risk factors in preschool children of urban Bangalore, India: acrosssectional study. Eur J Dent. 2012;6(2):141-152. https://dx.doi. org/10.1055/s-0039-1698943

16. Salama F, Abobakr I, Al-Khodair N, Al-Wakeel M. Comparison of Saudi child versus parent-report of child tooth-brushing practices. Niger J Clin Pract. 2016;19(4):449-454. https:// dx.doi.org/10.4103/1119-3077.183294

17. Kuriakose S, Prasannan M, Remya KC, Kurian J, Sreejith KR. Prevalence of early childhood caries among preschool children in Trivandrum and its association with various risk factors. Contemp Clin Dent. 2015;6(1):69-73. https://dx.doi. org/10.4103/0976-237X 
18. Eleuterio ASL, Cota ALS, Kobayashi TY, Silva SMB. Clinical Evaluation of the Oral Health of Children in the Cities of Alfenas and Areado, MG, Brazil. Pesq Bras Odontoped Clin Integr. 2012;12(2):195-201. https://dx.doi.org/10.4034/ PBOCI.2012.122.07

19. Kato T, Yorifuji T, Yamakawa M, Inoue S, Saito K, Doi H, et al. Association of breast feeding with early childhood dental caries: Japanese population-based study. BMJ Open. 2015;5(3):1-9. https://dx.doi.org/10.1136/bmjopen-2014-006982

20. Peltzer K, Mongkolchati A. Severe early childhood caries and social determinants in three-year-old children from Northern Thailand: a birth cohort study. BMC Oral Health. 2015;15(108):1-7. https://dx.doi.org/10.1186/s12903015-0093-8

21. Folayan MO, Kolawole KA, Oziegbe EO, Oyedele T, Oshomoji OV, Chukwumah NM, et al. Prevalence, and early childhood caries risk indicators in preschool children in suburban
Nigeria. BMC Oral Health. 2015;15(72):1-12. https://dx.doi. org/10.1186/s12903-015-0058-y

22. Hu S, Sim Y, Toh J, Saw S, Godfrey K, Chong YS, et al. Infant dietary patterns and early childhood caries in a multiethnic Asian cohort. Sci Rep. 2019;9(1):852. https://dx.doi. org/10.1038/s41598-018-37183-5

23. American Academy of Pediatric Dentistry. Guideline on Fluoride Therapy, 2018 [2020 Jan 15] Available from: <https://www. aapd.org/media/Policies_Guidelines/BP_FluorideTherapy.pdf>

24. Lee JY, Giannobile WV. Taxes on sugar-sweetened beverages: a strategy to reduce epidemics of diabetes, obesity, and dental caries? J Dent Res. 2016;95(12):1325-1326. https:// dx.doi.org/10.1177/0022034516668788

Received on: 4/3/2020 Final version resubmitted on: 11/4/2020 Approved on: 2/6/2020 